\title{
Textual Aspect of Friday Sermon Book and Relevance to Javanese Language Learning Material
}

\author{
Yudi Sahrul Sidik ${ }^{1}$, Suyitno ${ }^{2}$, Prasetyo Adi Wisnu Wibowo ${ }^{3}$, and Kundharu Saddhono ${ }^{4}$ \\ \{yudisidik0@gmail.com¹,yitsuyitno52@gmail.com², \\ prasetyoadiwisnuwibowo@yahoo.co.id ${ }^{3}$, kundharu_s@staff.uns.ac.id ${ }^{4}$ \} \\ 1,2,3 Sebelas Maret University, Surakarta, Indonesia
}

\begin{abstract}
The Javanese Friday sermon Book is a collection of Friday sermon commonly used by Ulamas. Different from the general Friday sermon, the Javanese Friday sermon is often difficult to be understood. The Javanese Friday sermon preaching text content should be in accordance with the rules of discourse, then the researcher will use textual analysis methods such as the use of lexical aspects in forming a good discourse. The research result shows that the Javanese Friday sermon speech book is in accordance with the principle of good discourse with the lexical aspect includes: 1; Repetitions, 2; Synonyms, 3; Collocation, 4; Hyponym. Seen from the lexical aspect, this Friday sermon book by Achmad Sunarto can be used as Javanese learning material.
\end{abstract}

Keywords: Discourse, Friday sermon, Lexical Cohesion

\section{INTRODUCTION}

The Javanese Friday sermon book is a collection of Friday sermon commonly used by Ulamas in Boyolali. Different from the general Friday sermon, the Javanese Friday sermon is often difficult to be understood. The Javanese Friday sermon Book's content should be in accordance with the rules of discourse

Friday sermon is the art of conversation to audiences in which there is a message [1]. In essence the Friday sermon means a will to ward off the audiences both in the form of promise of happiness and the threat of misery. Friday sermon is one of the worship established by the Islamic Shariah which is held simultaneously with the Friday prayer [2]. Friday sermon is an important activity for the development of religious life and society. This is because besides it is a form of ritual worship, it also serves as a very strategic medium for conveying advice, ideas and social information, and religious. It also offer ideas of renewal for the sake of advancement, increase knowledge and religious insight, and become an effective and efficient media of dakwah [3].

The Friday sermon in Arabic is khutbatul-Jumah meaning Friday sermon advice or Friday's discourse. The Friday sermon as an Islamic ritual uses to convey the message of taqwa towards Allah subhānahu wata'ālā. Taqwa is God consciousness to be nurtured by performing what Allah SWT commands and keeping away from what He forbids [4]. Thus, 
the Friday sermon is the advice of preachers who preach to the congregation as a speech partner in the mosque spoken on Friday before the Friday prayers are fulfilled.

Discourse is a form of language use, and Discourse Analysis (DA) is the analytical framework which was created for studying actual text and talk in the communicative context. Fitch believes that the early DA focused on the internal structure of texts. With the emergence of Systemic-Functional Linguistics [5]. Discourse as the most complete unit of language, in the grammatical hierarchy is the highest or largest grammatical unit. Discourse is realized in the form of a complete essay (novels, books, encyclopedia series, etc

Discourse is the highest and most complete language unit. Discourse is a complete recording of the language of communication events, both oral and written [6]. Cohesion is a way of how one component relates to another, whose entire function can be used to mark the relationship between elements of language. In other words, cohesion is a relationship between one and another element of language or interfaith relations, which has a semantic relationship between the elements contained in the text, cohesion is said to be a discourse that has the function of forming the context of a text [7]

Cohesion has an important role to help the reader interpreting the text. Besides that, through logical cohesion between events, the meaning contained, and the harmony of relations between elements in the discourse are well interwoven to form a good discourse [8]. Lexical cohesion is the interaction of the elements in the discourse semantically, Lexical cohesion has two functions: first, to link word and word, phrase and phrase within a text. Second, it is used to indicate co-oc currence of words which meanings are related in the same environment [9]. Lexical cohesion in discourse can be divided into six kinds: 1) Repetition, 2) synonym, 3) collocation, 4) collocation, 5) antonym, 6) equivalence. Théorie Sens-Texte, qu'un outil de description du sens des unités lexicales [10]

Sesorah is an activity of speaking in public or giving speech to express his opinion, or give an idea of something. Sesorah are usually delivered by one who gives speech and statements about an important matter / event that should be discussed with Javanese. Sesorah is one of the material of Javanese language lessons.

The focus of this research is the Khutbah "larangan tumindak zhalim" one of the titles in the book of Javanese Friday sermon Prayer by Achmad Sunarto, since lexical cohesion is one of the discourse-making elements, the discourse itself can be either oral or written as the Friday sermon. This study focused on discourse analysis on lexical cohesion. The analysis aims to describe the discourse prolem in this Javanese Friday sermon as follows: what is the lexical cohesion in Javanese Friday sermon book by Achmad Sunarto

\section{METHOD}

The research method used in this study is qualitative desciptive and content analysis method is used to analyze the content of a discourse. This research is a descriptive qualitative research done by examining the object found and interpreting the relationship of various elements in it [11]. Data collection techniques in this study are content analysis. Data validity is done through triangulation of source and triangulation theory. The sampling technique used in this research is purposive sampling on Javanese Friday sermon book by Achmad Sunarto. While data analysis uses interactive data analysis, namely data collection, data reduction, data display, and conclusion drawing.

\section{RESULT AND DISCUSSION}

Cohesion are divided into two aspects: grammatical and lexical cohesion 


\subsection{Lexical Cohesion in the discourse of Javanese Friday sermon by Achmad Sunarto entitled "larangan tumindak zhalim"}

Lexical cohesion in discourse can be divided into six types, namely (1) repetition, (2) synonymy, (3) collocation, (4) hyponym, (5) antonym (opposite word), (6) equivalence. But this paper will only discuss four of the six existing lexical cohesion due to data limitations. The results of the analysis of lexical cohesion in Javanese Friday sermon book by Achmad Sunarto entitled "larangan tumindak zhalim" will later be presented.

\section{a. Repetition}

Repetition is repeating of lingual units (sounds, syllables, words, or sentence sections) that are considered important for putting pressure in an appropriate context. Based on the place of the lingual unit the reps are differentiated to nine: repedition epizeuksis, tautotes, anaphora, epistrofa, simploke, mesodiplosis, epanalepsis, anadiplosis, and complete repetition. The findings of repetition in lexical cohesion analysis are as follows:

1) Epizeuksis Repetition

Epizeuksis repetition is the repetition of the lingual unit (word) which is emphasized several times in a row.

"panjenengan sedaya kedah waspada. Ngatos-ngatos dhumateng punapa kemawon ingkang saged dumugiaken dhateng kerisakan lan getun. Lan panjenengan sedaya kedah ngatos-ngatos sampun ngantos dumawah zhalim ingkang ateges nganingaya."

In quotation 1) above, the words ngatos-ngatos are repeated several times in succession to emphasize the importance of the word ngatos-ngatos in that context.

2) Mesodiplosis Repetition

Mesodiplosis repetition is the repetition of lingual units in the middle of a row or sentence in a row.

"Jalaran tindhak nganingaya punika dados pepeteng benjang ing dinten kiamat. Ugi kedah tansah dipunemuti bilih tindhak nganingaya punika benjang ing tembe tamtu wonten piwalesipun, boten dhumateng ingkang tumindak nganingaya kemawon nanging ugi dhumateng putra wayahipun."

In each sentence above there is a repetition of the "nganingaya" lingual unit located in the middle of the sentence in a row, such repetition by the author is intended to emphasize the meaning of the repeated lingual unit, namely the prohibition of persecution because the act is not commendable to anyone.

3) Anadiplosis Repetition

Anadiplosis repetition is the repetition of the last word or phrase of the line or the sentence becomes the first word or phrase in the next line or sentence "panjenengan sedaya kedah waspada. Ngatos-ngatos dhumateng punapakemawon ingkang saged dumugiaken dhateng kerisakan lan getun. Lan panjenengan sedaya kedah ngatos-ngatos sampun ngantos dumawah zhalim ingkang ateges nganingaya. Nganingaya dhumateng badanipun piyambak, utawi dhateng sesami titah."

Seen in the sermon above, the word "nganingaya" at the end of the first line becomes the first word on the second line of the sermon passage above

\section{b. Synonyms}

Synonymy can be defined as another name for the same thing, or phrase whose meaning is more or less the same as another. Synonymy is one of the lexical aspects to support cohesion of discourse. Synonymy serves to establish a corresponding meaning relationship between a particular lingual unit with other lingual units in the discourse. 
Based on the lingual form of the synonym can be divided into five kinds, namely (1) synonymy between morphemes (free) with morphemes (bound), (2) words with words, (3) words with phrases or otherwise, (4) phrases with phrases, (5) clause / sentence with clause / sentence. The synonymy findings in lexical cohesion analysis are as follows:

Synonymous words with words

1) "Mangga kita ningkataken taqwa kita dhumateng Allah ta'ala, ateges nglampahi dhateng sedaya perintah-perintahipun tuwin nebihi dhateng sedaya awisan-awisanipun. Kanthi taqwa kita badhe wilujeng donya tuwin akhirat. Panjenengan sedaya kedah tansah cecepengan dhateng punapa kemawon ingkang dados kawilujengan, keselametan, kebahagiaan tumrap panjenengan sedaya."

2) "Perlu panjenengan mangertosi sinten kemawon ingkang gandhulan lan cecepengan dhawuhdhawuhipun Allah ta'ala, dhawuh-dhawuh wau badhe dados sebab kabegjan ingkang kiyat. Lan sinten kemawon ingkang mengo sangking dhawuh-dhawuhipun Allah ta'ala, tiyang wau badhe dipunrakit kalayan syetan."

3) "kangge ngawekani kezhaliman ingkang taksih grebda wonten ing bumi indonesia punika, mangga kita giyataken amar ma'ruf nahi mungkar, keranten amar ma'ruf nahi mungkar punika langkung nggatosaken kawigatosan ingkang wajib lan kedah katindakaken dening sedaya tiyang muslim lan muslimat.

In quotation 1) the word kawilujengan is synonymous with the word keselametan, the word kawilujengan and keselametan has the same meaning. In quotation 2) the word gandhulan synonymous with the word cecepengan, the word gandhulan and cecepengan has the same meaning. In quotation 3 ) the word wajib synonymous with the word kedah, the word wajib and kedah has the same meaning.

\section{c. Collocation}

Column or word collocation is a particular association in using word choices that tend to be used side by side. Disaggregated words are words that tend to be used in a particular domain or network, for example in educational networks will be used words related to education issues and the people involved in it. The findings of collocation in lexical cohesion analysis are as follows:

1) "Mangga kita ningkataken taqwa kita dhumateng Allah ta'ala, ateges nglampahi dhateng sedaya perintah-perintahipun tuwin nebihi dhateng sedaya awisanawisanipun. Kanthi taqwa kita badhe wilujeng donya tuwin akhirat. Panjenengan sedaya kedah tansah cecepengan dhateng punapa kemawon ingkang dados kawilujengan, keselametan, kebahagiaan tumrap panjenengan sedaya."

2) "panjenengan sedaya kedah waspada. Ngatos-ngatos dhumateng punapakemawon ingkang saged dumugiaken dhateng kerisakan lan getun. Lan panjenengan sedaya kedah ngatos-ngatos sampun ngantos dumawah zhalim ingkang ateges nganingaya."

Quotes on discourse 1) above appear the use of words taqwa, perintahperintahipun, and awis-awisanipun, which mutually collocation and support cohesion of the discourse. Likewise in the discourse 2) above, appears the use of zhalim, and nganigaya, which mutually and support the discourse of the discourse, and also on the discourse

d. Hyponym

Hyponymism can be interpreted as a unit of language whose meaning is considered to be a division of the meaning of other lingual units [12]

"Mangga kita ningkataken taqwa kita dhumateng Allah ta'ala, ateges nglampahi dhateng sedaya perintah-perintahipun tuwin nebihi dhateng sedaya awisan-awisanipun. Kanthi taqwa kita badhe wilujeng donya tuwin akhirat. Panjenengan sedaya kedah tansah 
cecepengan dhateng punapa kemawon ingkang dados kawilujengan, keselametan, kebahagiaan tumrap panjenengan sedaya." [13]

On the excerpts of the Friday sermon above which is a hypernim or superordinate is "taqwa", meanwhile the hyponym is "perintah-perintahipun" and "awis-awisanipun". Similar to Sukriyah's article about lexical cohesion, there are differences, namely in his article, he directly analyzes lexical cohesion in the form of synonymy, antonymy and repetition while in this paper analyzes all existing lexical cohesion and the subsequent differences in the object analyzed for the object being analyzed by Sukriyah the daily news paper Kompas while in this paper the analysis is the Friday sermon book like the following quote. This research aims to describe discourse coherence which is supported by aspects of lexical cohesion, limited to the use of synonyms, antonyms, and repetition in the cernak, romance,and short stories in Kompas [14]

\subsection{Relevance with Javanese Language Learning Material}

The relation between Javanese Friday sermon with sesorah can be seen in the curriculum and lesson plan specifically on Javanese subject. Material about sesorah is put in the lesson plan and also curriculum., sesorah's structure itself has the same structure as speech but it is using Javanese.

Friday sermon's structure rather similar to speech, it has slight difference that Friday preaching has special form, function and characteristics. For example, the specialities present in the opening of preaching in Arabian language which is then followed by javanese language [15]. Friday sermon can be used as Javanese material lesson by looking at it structure, comprehensiveness and discourse compactness. Friday sermon consist of religiuos thaught like the relation between human and human then relation between human and God, so that it is match to the character education especially the religious value which become the main attention of Indonesian education nowadays. Rahayu said that religion also regulates the relationship between humans with humans and humans with nature. Indeed, religion is not only about the outward aspect of life but also the total of every human self in the integration of the relationship into the oneness of God [16].

\section{CONCLUSION}

The parts of lexical cohesion present in the discourse include: (1) Repetition, (2) synonymy, (3) collocation, (4) hyponym. The use of lexical cohesion in the formation of discourse in the Javanese fridaysermon book by Achmad Sunarto has been very well seen from the cohesion of his discourse or the use of lexical aspect. Seen from the lexical aspect which is one aspect of forming a good discourse, this book of Friday sermon by Achmad Sunarto can be used as Javanese learning material.

\section{REFERENCES}

[1] L. Muhyiddin. "Gaya Bahasa Khutbah Jum'at (Kajian Pola Retorika)”. At-Ta'dib, Vol. 8 No. 2. pp. 300, 2013.

[2] E. Jusuf. "Analisis Minat Jamaah Masjid Terhadap Penyampaian Khutbah Jumat di Kecamatan Talaga Jaya Kabupaten Gorontalo". Madani, Vol. 4, No. 1, pp. 75, 2014.

[3] M. Tahir. Khutbah Jum'at di Kota Samarinda (Analisis Kesiapan Para Khotib di Kota Samarinda). Fenomena, Vol. 5, No. 2, pp. 229, 2013.

[4] K. Saddhono. "The Discourse Of Friday Sermon In Surakarta A Socio-Pragmatic Study". Wacana, Vol. 14, No. 1, pp. 146-147, 2012. 
[5] Rahimi and Riasati. "Critical Discourse Analysis: Scrutinizing Ideologically Driven Discourses. Humanities and Social Science". International Journal of Humanities and Social Science, Vol. 1, No. 16, pp. 107, 2011.

[6] I. D. P. Wijana. Analisis Wacana Pragmatik Kajian Teori dan Analisis. Surakarta: Yuma Pustaka, 2011.

[7] A. A. Wulandari. "Pemarkah Kohesi Leksikal Dan Kohesi Gramatikal (Analisis pada Paragraf dalam Skripsi Mahasiswa Pendidikan Bahasa dan Sastra Indonesia)". Dialektika: Jurnal Pendidikan Bahasa, Sastra, dan Matematika, Vol. 1, No. 1, pp. 74, 2015.

[8] Y. Dwinuryati. "Analisis Kohesi Gramatikal dan Leksikal pada Teks Eksposisi Siswa Kelas 10 Sekolah Menengah Atas". Scholaria: Jurnal Pendidikan dan Kebudayaan, Vol. 8 No. 1, pp. 61-69, 2018.

[9] P. Dyah. "Types Of Lexical Cohesion Found In Lyric Of The Script's Song". Humanis Vol. VII, No. 1, pp. 1-2, 2013.

[10] MEL'ČUK et POLGUÈRE, La définition lexicographique selon la Lexicologie Explicative et Combinatoire, Cahiers de lexicologie, No 109, pp. 61-91, 2016.

[11] H. B. Sutopo. Metodologi Penelitian Kualitatif: Dasar Teori dan Terapannya dalam Penelitian. Surakarta: UNS Press, 2006.

[12] Sumarlam. Teori dan Praktik Analisis Wacana. Surakarta: KATTA/bukukata, 2013.

[13] A. Sunarto. Khutbah Jum 'ah Basa Jawi. Sukoharjo: CV. Cendrawasih, 2014.

[14] S. Sukriyah. "Kohesi Leksikal Sinonimi, Antonimi, dan Repetisi Pada Rubrik Cerita Anak, Cerita Remaja, dan Cerita Dewasa dalam Surat Kabar Harian Kompas”. Aksara, Vol. 30, No. 2, pp. 267, 2018.

[15] K. Saddhono. "The Language Usage in The Discourse of Friday Preaching in Java, Indonesia". Karsa, Vol. 21, No. 2, pp. 239, 2013.

[16] D. R. W. Rahayu. "The Education Values Of Susuk Wangan Tradition For Character Forming In The Milenial Era”. El Harakah, Vol. 20, No. 2, pp. 224, 2018. 